\title{
CROSS-COUNTRY LEARNING IN PUBLIC PROCUREMENT: AN EXPLORATORY STUDY
}

\author{
Kimberly Nijboer, Shirin Senden, and Jan Telgen*
}

\begin{abstract}
All countries use public procurement to some degree to further policy objectives such as sustainability, innovation, fighting fraud and corruption, value for taxpayers' money etc. Countries may learn from past successes and failures in other countries while implementing these policies: cross-country learning. In this exploratory study, we investigate cross-country learning across two frequently used policy areas: sustainability and innovation. A threefold methodology was used that consisted of (1) an extensive review of scientific literature complemented by (2) a thorough examination of policy documents and (3) interviews with leading public procurement experts from 10 countries including both developing and developed countries. The main findings indicate that there is no hard evidence for cross-country learning. Even if cross-country learning would exist, the lessons learned seem to remain largely implicit.
\end{abstract}

\section{INTRODUCTION}

Public procurement is commonly seen as a way to achieve policy goals. According to a report released by the International Research Study of Public Procurement (Knight, Caldwell, Harland, \& Telgen, 2004), public procurement is increasingly viewed as more encompassing than a means of saving money for governments. In fact, public procurement is more and more associated with being a lever of social reform. In the European Union, the Treaty of Lisbon has

* Kimberly Nijboer, MSc Business Administration at the University of Twente, and Shirin Senden, MSc Finance \& Investments at the Rotterdam School of Management, Erasmus University, performed this study as part of the BSc International Business Administration, Department of Technology Management and Supply, University of Twente. Jan Telgen, Ph.D., is Professor, Department of Technology Management and Supply, University of Twente. His research interest is in supplier selection and developing public procurement professionalism.

Copyright $\odot 2017$ by PrAcademics Press 
addressed the increased need of incorporating the social and environmental aspects of public procurement (European Parliament, 2010). Examples of such policy goals are sustainability and innovation, which both seem to be well-established and widely accepted policy goals that may lead to value creation for society.

The ways of implementing these policy goals through public procurement vary per country. They may be implemented, e.g., through specific laws or regulations, or the government may use its own procurement volume 'to lead by example'. Furthermore, not all countries implemented their variant at the same time. This means that there is ample opportunity for cross-country learning: a country can learn from the experiences of other countries (both good and bad experiences) when implementing public procurement policies.

Here, we investigate to what extent cross-country learning exists in practice. We do so by considering two policy areas: sustainability and innovation. A threefold methodology that combines theory and practice was used in this study that consists of: (1) an extensive review of the literature, complemented by (2) a thorough examination of policy documents and (3) interviews with leading public procurement experts and practitioners from various countries.

The paper is structured as follows. First, we consider public procurement and the rise of sustainable and innovative public procurement goals. Next, the threefold methodology of the study is discussed in depth. Then, we present the results of each of the three parts of the study. We conclude with a discussion on the outcomes of the study.

\section{PUBLIC PROCUREMENT POLICIES: WHY DO THEY MATTER?}

This section will outline the economic, social, and environmental relevance of public procurement policies and will review how issues of sustainability and innovation have been integrated into public procurement.

\section{Public Procurement and Its Wider Impact}

For the purpose of this study, it is important to define the key concept of public procurement. In general, public procurement can be seen as public spending for works, goods, and services. Governments, of course, regulate the way public procurement is 
executed by their laws and regulations. Through these, they may even require certain secondary goals to be taken into account in public procurement (as did the EU). These rules and regulations may have wider applicability than the direct government spending alone.

It is worth noting that government spending is huge. In Europe, it is estimated that almost $€ 2$ trillion is spent on public procurement on an annual basis (European Commission, 2011; Procurement of Innovation Platform, 2014). In general, approximately $15-20 \%$ of the GDP and $40-90 \%$ of the public budget is spent on the procurement of goods, services, and works (European Commission, 2016). Due to the sheer magnitude of these budgets, national governments can use their market power to achieve financial, social, and environmental outcomes directly, but also to stimulate the entire marketplace to produce and consume more sustainably and innovatively (ICLEI, 2007). Therefore, public procurement policies that encourage governments to engage in sustainability and innovation have become more and more important to address both technical developments and socioeconomic challenges (Office of Government Commerce, 2011; Rolfstam, 2013; Lember, Kattel, \& Kalvet, 2014; Procurement of Innovation Platform, 2014).

Achieving 'value for money' in public procurement, in terms of price and quality, is often mentioned as the primary goal, whereas the contribution to other policy goals is referred to as a secondary goal.

\section{Sustainable and Innovative Public Procurement Policies}

Sustainable and innovative public procurement policies can be implemented at multiple levels, both on the national level as well as on various local or organizational levels. The focus of this study is on national governments. The implementation of these public procurement policies can create benefits for national governments in multiple ways. First of all, they can create financial benefits. According to the UK's Office of Government Commerce (2011), implementing public procurement policies on innovation is a way to achieve value for money by optimally combining life-cycle costs and quality to meet public needs. Sustainable public procurement policies can also result in cost effectiveness, especially when the whole-life costs are taken into account (ICLEl, 2007; United Nations, 2008; European Commission, 2011). Next to these economic advantages in terms of cost savings, sustainable and innovative public procurement 
policies can result in a contribution towards environmental and social goals (Sustainable Procurement Task Force, 2006; ICLEI, 2007; United Nations, 2008; European Commission, 2010). Also, public procurement policies on sustainability and innovation can assist national governments to achieve the goals of international agreements such as the Paris Agreement (2015) and to improve their public image (ICLEl, 2007; Procurement of Innovation Platform, 2014). In sum, these benefits could trigger national governments to lead by example.

\section{Barriers}

The implementation of sustainable and innovative policies in public procurement may be restrained by factors such as risk aversion, a lack of skills and capabilities, and limited resources (Harland, Bakker, Caldwell, Phillips, \& Walker, 2005; Sustainable Procurement Task Force, 2006; UNEP, 2013; Procurement of Innovation Platform, 2014). Another important barrier that should be mentioned is the fact that public procurement regulations are frequently considered to be a purely financial or administrative duty. Aligning this duty with broader policy goals is often not considered as the most preferred mechanism to achieve the desired goals (Procurement of Innovation Platform, 2014). National governments also tend to hold the belief that public procurement policies on sustainability and innovation are more costly (Kalvet \& Lember, 2010; European Commission, 2015). However, the Sustainable Procurement Task Force (2006) states that these kinds of policies do not need to cost more since they improve performance by cutting out waste and by seeking innovative solutions. Lastly, the lack of political commitment and technical capacity of governments to implement sustainable and innovative public procurement policies is mentioned as another barrier (United Nations, 2008).

\section{Implementing Public Procurement Policies}

Despite these barriers, governments have become increasingly active in implementing public procurement policies and they do so in various ways. These ways may range from legal requirements to 'soft' suggestions for practice. For example, it is mandatory to use other award criteria than price alone in the European Union. Therefore, buying agencies must also specify other criteria such as quality to be used in selecting the best bid (European Directives, 2014). Other 
legal requirements may be the use of specific requirements that secure a minimum level of sustainability. A softer form to stimulate sustainability in public procurement is to state a target for the percentage of sustainable public procurement to be reached over a certain time period or to stimulate 'buying green' by the use of product guidelines, ecolabels and life cycle costing (Ministerie van Infrastructuur en Milieu, 2010).

An example of a legal requirement imposed on innovation would be to make the use of functional specifications mandatory or the preferred way of specifying the needs of the buying agency. However, most innovation policies merely advocate specific ways of acting without any obligation or they only provide advice on stimulating innovation through public procurement (PIANOo, 2011).

It will be clear that different ways of implementing policy goals through public procurement may have very different outcomes. Even though the situation will vary per country (Knight et al., 2004), there are at least lessons to be learned from one country to the other: that is the subject of this study.

\section{METHODOLOGY}

The purpose of this study is to analyze to what extent crosscountry learning really exists and to indicate whether there are lessons learned from one country to another. We do so by using the policy areas of sustainability and innovation as examples for the broader field of cross-country learning on public procurement.

The methodology of this study is threefold and consists of: (1) an extensive review of scientific literature complemented by (2) a thorough examination of policy documents and (3) interviews with leading public procurement experts. According to Grix (2004), the triangulation of three different methods helps to minimize bias in the findings and to shed more light on the topic from different angles. Therefore, a threefold methodology was chosen, as scientific literature alone does not provide all information that can be found in policy documents and vice versa. Besides, information that cannot be found in policy documents could be gathered by conducting interviews. Thus, interviews with leading procurement experts and practitioners are another way to gain complementary insights in order 
to combine theory and practice. The threefold methodology will be explained in this section.

\section{Scientific Literature}

The first part consists of an extensive review of scientific literature on public procurement policies on sustainability and innovation. In order to initiate an effective search strategy, we will use the 12-step framework of Kable, Pich, and Maslin-Prothero (2012) as shown in Table 1.

TABLE 1

Search strategy: 12-step framework by Kable et al. (2012)

\begin{tabular}{|c|c|}
\hline Step 1 & $\begin{array}{l}\text { Provide a purpose statement } \\
\text { The purpose of this paper is to find out to what extent cross- } \\
\text { country learning in public procurement policies on sustainability } \\
\text { and innovation exists. }\end{array}$ \\
\hline Step 2 & $\begin{array}{l}\text { Document the databases or search engines used in your search } \\
\text { strategy } \\
\text { Scopus was used to search for relevant literature because it is the } \\
\text { largest database of peer-reviewed literature.* }\end{array}$ \\
\hline Step 3 & $\begin{array}{l}\text { Specify the limits applied } \\
\text { Our strategy focuses on peer-reviewed papers about sustainability } \\
\text { and innovation in national public procurement: } \\
\text { - } \quad \text { Registered in journals, which serve as a sound quality measure } \\
\text { since feedback is provided by a selected group of professional } \\
\text { reviewers (Solomon, 2007); } \\
\text { - } \quad \text { Available in English; } \\
\text { - Published since the } 1990 \text { s, because this is when both themes } \\
\text { have become relevant public procurement issues (Edler \& } \\
\text { Georghiou, 2007; UNEP, 2013); } \\
\text { - Listed under the cluster 'Social Sciences \& Humanities' in } \\
\text { Scopus, which includes studies on public procurement, } \\
\text { sustainability, and innovation. }\end{array}$ \\
\hline Step 4 & $\begin{array}{l}\text { List the inclusion criteria and exclusion criteria } \\
\text { The following inclusion criteria were specified: } \\
\text { - Both single- and multi-country studies were found to be useful } \\
\text { (i.e. multi-country studies refer to those papers that compare } \\
\text { two or more countries and are especially valuable for this } \\
\text { study, because of the multi-country perspective that is taken; } \\
\text { whereas single-country studies can also be valuable since }\end{array}$ \\
\hline
\end{tabular}


TABLE 1 (Continued)

\begin{tabular}{|c|c|}
\hline & $\begin{array}{l}\text { those studies can be used to illustrate what countries could learn } \\
\text { from each other). } \\
\text { - The following exclusion criteria were specified: } \\
\text { Papers that are not available in English and/or do not focus on } \\
\text { national public procurement (e.g. peer-reviewed papers that } \\
\text { investigate the concept of sustainable or innovative procurement } \\
\text { in the private sector). }\end{array}$ \\
\hline Step 5 & $\begin{array}{l}\text { List the search terms used } \\
\text { It was observed that a wide variety of search terms is used in the } \\
\text { field and, thus, combinations of search terms will be used to cover } \\
\text { a wider range of papers: } \\
\text { 1. Public or Government; } \\
\text { 2. Procurement; } \\
\text { 3. Policy; } \\
\text { 4. Sustainability or Sustainable or Green or Environmental; } \\
\text { 5. Innovation or Innovative. }\end{array}$ \\
\hline Step 6 & $\begin{array}{l}\text { Document the search process } \\
\text { The process was initiated in June } 2015 \text { and is documented in } \\
\text { Appendix } 1 \mathrm{~A} \text {. In total, } 804 \text { results were found, which were then } \\
\text { narrowed down during the second step. We searched within the } \\
\text { results for peer-reviewed papers directed at public procurement } \\
\text { policies on sustainability and innovation. Finally, there were } 220 \\
\text { peer-reviewed papers left for sustainability and } 207 \text { papers for } \\
\text { innovation, which were used to assess for relevance. }\end{array}$ \\
\hline Step 7 & $\begin{array}{l}\text { Assess retrieved papers for relevance } \\
\text { Two authors assessed the papers independently by reading the } \\
\text { title and abstract using the inclusion and exclusion criteria, which } \\
\text { increases the validity of our research. Next, we compared the } \\
\text { shortlists of relevant papers that were made independently. In } \\
\text { case of any differences, we discussed this to come to an } \\
\text { agreement on the initial selection. Afterwards, both } \\
\text { backreferencing and an author search in ResearchGate, for } \\
\text { authors who appeared more than once in our overview, were } \\
\text { applied to find more potentially relevant papers. Again, the same } \\
\text { approach was used to assess their relevance. }\end{array}$ \\
\hline Step 8 & $\begin{array}{l}\text { Document a summary table of included papers } \\
\text { Appendices } 1 \mathrm{~B} \text { and } 1 \mathrm{C} \text { list the peer-reviewed papers that were } \\
\text { found and met the inclusion criteria. Papers indicated with } \mathrm{a} \text { '* } \\
\text { were found by means of back referencing }\end{array}$ \\
\hline Step 9 & $\begin{array}{l}\text { Provide a statement specifying the number of retrieved papers } \\
\text { In total, } 6 \text { peer-reviewed papers were found for sustainability and } \\
7 \text { papers for innovation. Next, } 3 \text { additional papers were found by } \\
\text { means of backreferencing for sustainability. Lastly, the author }\end{array}$ \\
\hline
\end{tabular}


TABLE 1 (Continued)

\begin{tabular}{|c|c|}
\hline & $\begin{array}{l}\text { search did not yield more results for both themes, since most } \\
\text { papers did not focus on national public procurement, or were } \\
\text { conference papers. The relatively high number of papers that } \\
\text { were found by means of backreferencing for sustainability can be } \\
\text { explained by the fact that } 2 \text { papers are published in a journal that } \\
\text { is listed underneath 'environmental science', which belongs to the } \\
\text { subject cluster of 'Physical Sciences' in Scopus. The paper of } \\
\text { Walker and Brammer (2009) could not initially be found because } \\
\text { the query requires the inclusion of the word 'policy'. The fact that } \\
0 \text { peer-reviewed papers of innovation were found can be } \\
\text { explained by the already scarce amount of literature that met our } \\
\text { inclusion criteria in the first place. }\end{array}$ \\
\hline Step 10 & $\begin{array}{l}\text { Conduct quality appraisal of retrieved literature } \\
\text { The quality appraisal was implicit because only peer-reviewed } \\
\text { papers were selected. }\end{array}$ \\
\hline Step 11 & $\begin{array}{l}\text { Critically review the literature } \\
\text { All selected peer-reviewed papers were examined thoroughly to } \\
\text { analyze to what extent cross-country learning exists and to } \\
\text { indicate whether there are lessons learned from one country to } \\
\text { another. If there were any indicators that cross-country learning } \\
\text { exists, those indicators were expected to be explicitly or implicitly } \\
\text { stated. }\end{array}$ \\
\hline Step 12 & $\begin{array}{l}\text { Check the reference list for accuracy } \\
\text { The reference list is up-to-date and critically appraised. }\end{array}$ \\
\hline
\end{tabular}

*Source: http://www.elsevier.com/solutions/scopus.

\section{Policy Documents}

The second part consists of thoroughly examining public procurement policy documents on sustainability and innovation from selected countries based on the interviews' sample composition. Appendix 2A lists the analyzed policy documents. We looked at government websites since governments are responsible for regulating public procurement. Only websites that are available in English or Dutch were examined. A distinction was made between mandatory public procurement regulations and policy initiatives that are more voluntary. In addition, national procurement associations are expected to document this information. Therefore, as a doublecheck, association websites were also analyzed. 
When a policy on sustainability and/or innovation was identified, we searched for information on the origins of this policy with regard to cross-country learning. The same search terms that were used during the literature search process were also applied to find policy documents. The document search was carried out between May and mid-June 2015. Again, this process was independently executed by two authors to avoid overlooking relevant policies. Appendices $2 \mathrm{~B}$ and $2 \mathrm{C}$ list the results that were found. Within these documents, we searched for words such as learn, inspire, copy, and adopt.

Our policy analysis method was inspired by the "open systems" model from Snider and Rendon that can be used to analyze public procurement policies (2008). Nevertheless, some adaptations were made to align the model with the concept of cross-country learning in public procurement. In Figure 1, the following components can be distinguished: national policy influences, inputs, policies developed and applied, effects of the policy, and diffusion. The Iceberg metaphor was used to make a distinction between elements that are perceived to be 'above the surface' and elements that are perceived to be 'below the surface'.

FIGURE 1

Policy Analysis Method

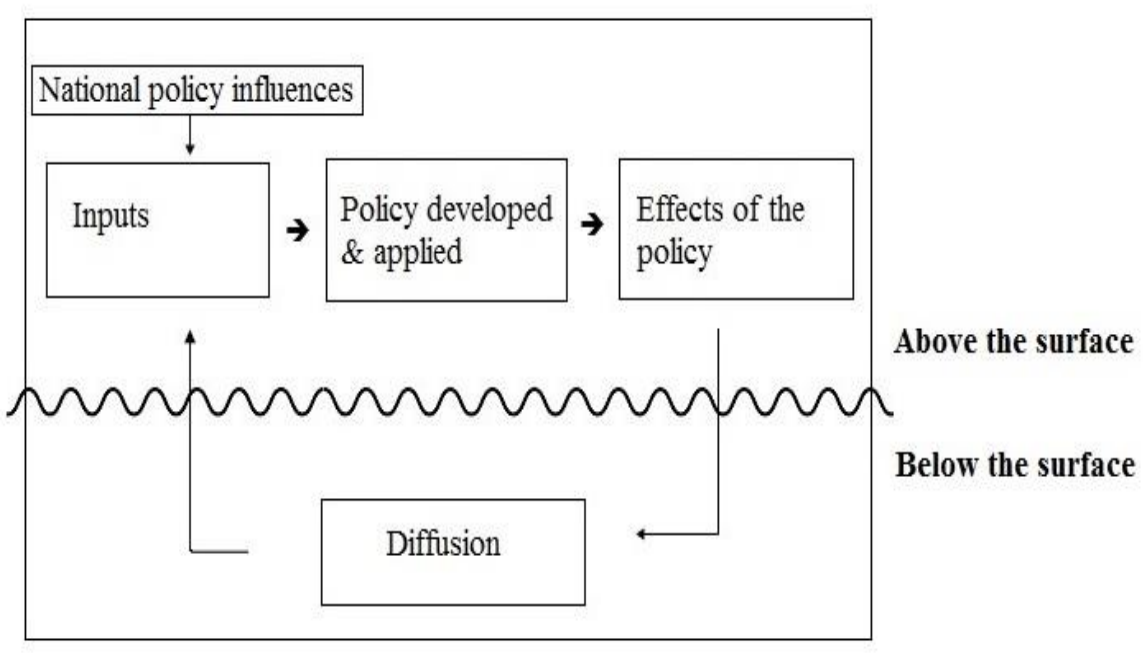


The model's elements 'national policy influences', 'inputs', 'policies developed and applied', and 'effects of the policy' were seen as explicit and were indicated as 'above the surface'. The element 'diffusion', however, was viewed as implicit and was marked as 'below the surface'. We perceive cross-country learning to take place at this 'diffusion' stage. The process starts with 'inputs' that may evolve from 'national policy influences' (e.g. national government objectives). There may also be some input from the 'diffusion' stage. Other countries could already have implemented similar policies and may have gained adequate experiences. However, it is not clear if, and how, these lessons learned were transferred from one country to another. The inputs can be converted into new policies that are subsequently developed and applied, while these policies are likely to lead to certain effects. In turn, these can be used as new learning opportunities.

Since it is unclear how this process unfolds due to the implicitness of cross-country learning, the policy documents were examined to see if the policies have been formulated in response to national policy influences and/or cross-country learning. We thoroughly examined these documents in parallel to conducting the interviews. Through this, complementary information from the interviewees could be used to support our policy document search and vice versa.

\section{Interviews}

The third part consists of interviews with experts from both developing and developed countries. We chose for semi-structured interviews because they allow for a certain degree of freedom (Grix, 2004). The interview questions can be found in Appendix 3A. It should be noted that both predefined and questions that we formulated ad hoc were posed.

We used convenience sampling, which is a form of non-probability sampling that suits exploratory research (Adler \& Clark, 2015). In this study, we sampled from a list of experts that participated in the International Research Study on Public Procurement (IRSPP), which is a bi-annual meeting of high-ranking public procurement practitioners (i.e. usually the government $\mathrm{CPO}$ ) from various countries (Knight et al., 2004). It was taken into account that it is important to overcome sampling bias (Ghauri \& Grønhaug (2010). Therefore, public 
procurement experts from both developing and developed countries were included. In total, we contacted 25 experts of whom 10 were willing to participate. All interviews were conducted in the first two weeks of June 2015 via Skype, due to the interviewees' geographic spread. Table 2 provides randomly ordered information about the sample composition regarding each interviewee's function and the country they work in.

The interviews were conducted in English and the interviewees were promised that their answers will be kept confidential and anonymous. If necessary, we asked the interviewees to give some further explanations. Finally, we asked the interviewees if they had some remarks about issues that we might have overlooked.

After the interviews were conducted, the transcripts were immediately prepared (available upon request). Since the interviews were conducted in parallel to our policy document search, it was possible to process complementary information gathered through the interviews and vice versa.

During the analysis of the interviews, the focus was on examining to what extent cross-country learning exists and to find clues as to whether there are lessons learned from one country to another. Once again, the analysis was executed independently to enhance the validity.

TABLE 2

Sample Composition

\begin{tabular}{|l|l|}
\hline \multicolumn{1}{|c|}{ Country } & \multicolumn{1}{c|}{ Role } \\
\hline Bhutan & Regional Director at Office of SMEs \\
\hline Canada & President of Public Procurement Association \\
\hline Ethiopia & Country Coordinator for CIPS \\
\hline Germany & Head of Research at Central Purchasing Body \\
\hline Italy & Lecturer on Public Procurement \\
\hline The Netherlands & Professor of Materials Management \\
\hline Portugal & Director of Public Procurement Expertise Centre \\
\hline Sweden & Dean of Public Administration Department \\
\hline Uganda & Senior Procurement Manager \\
\hline The United States & Chief Procurement Officer \\
\hline
\end{tabular}




\section{FINDINGS \& RESULTS}

The findings and results of this study are discussed in the following three parts: (1) scientific literature, (2) policy documents and (3) interviews.

\section{Scientific Literature}

The scientific literature on both national sustainable and innovative public procurement policies is relatively scarce (Brammer \& Walker, 2011; Georghiou et al., 2013; Wan, 2014). This can also be confirmed by our study. After an extensive review of the scientific literature, only nine peer-reviewed papers were found for sustainability and seven papers for innovation that looked at national policies. This sample includes both single-country studies and multicountry studies. Although the studies that were found for sustainability focus on both developed and less developed countries, it was remarkable that the papers for innovation are mainly focused on the European Union (EU) and none of them focus on a developing country. The very few multi-country studies were more comparative in nature: the papers contained little explicit indication of cross-country learning in public procurement on sustainability and innovation, as will be demonstrated below.

\section{Frontrunners within the European Union}

Amann, Roehrich, Eßig, and Harland (2014) studied the current state of public procurement policies on sustainability across the member states of the EU and found that the majority of European countries developed a national action plan for incorporating sustainability into public procurement. The 'Green-7' countries (which are Austria, Denmark, Finland, Germany, the Netherlands, Sweden, and the UK) can be considered as frontrunners with respect to sustainable public procurement policies. Thus, the status of these countries as frontrunners could be seen as an opportunity to lead by example in order to stimulate the adoption of sustainable public procurement policy goals in other countries.

A similar pattern can be observed for public procurement policies on innovation. The UK is regarded as having the most systematic and advanced approach (Edler \& Georghiou, 2007). According to Myoken (2010), the UK was one of the first European countries to implement

a framework agreement that does not only foster innovation but also 
offers better public services. A specific example of an innovative public procurement policy in the UK is the White Paper Innovation Nation, which requires ministries to make a detailed plan of how they expect to stimulate innovation through expenditure. It was stated that Austria is one of the countries that have copied this concept of planning that necessitates departments to outline their needs and expectations to procure innovation (Georghiou et al., 2014). Unfortunately, the paper does not state what lessons Austria has learned from the UK when implementing the program and whether this program has been successful in Austria or not. Thus, there seems to be some room for mentioning here that Austria has taken an example of Britain's framework agreement. Nevertheless, the articles do not provide any explanations that explicitly discuss this process of cross-country learning in more detail.

Other countries, besides the UK, that took early initiatives are the Netherlands and Germany (Rolfstam, 2009). The leading status of these countries could also highlight their role to lead by example and to share their best practices to stimulate the uptake of sustainable and innovative public procurement policies around the world. For instance, the European Commission praised the Netherlands for its knowledge network system in which the government plays a key role in driving innovation (Myoken, 2010). Its exemplary role can be further illustrated by PIANOo, which is a Dutch platform for public procurement practitioners where experiences can be exchanged (Edler \& Georghiou, 2007; Myoken, 2010). However, mentioning that other countries such as the Netherlands and Germany also took early initiatives does not unravel anything about if, and how, they worked together or whether other countries have learned from them. Again, this only points to implicit examples from situations in which countries could have engaged in cross-country learning.

All in all, none of these studies explicitly mention anything about cross-country learning. Thus, the lessons learned seem to remain implicit at best. By solely reflecting on the idea that certain European countries have copied and implemented a similar version of a certain public procurement policy or initiative, it seems that the implicitness of cross-country learning remains intact, as far as it concerns the retrieved literature. The question remains how the process of crosscountry learning unfolds, but it could be that the global pattern differs from the one observed in the retrieved literature that discusses 
European public procurement policies on sustainability and innovation.

\section{The Spread of Sustainable and Innovative Public Procurement Policies on a Global Scale}

Most papers that discuss the global spread of sustainable public procurement policies seem to focus on developing countries, which already raises questions about whether, and if so how, the process of cross-country learning differs from developed countries. Although the number of countries that have adopted Green Public Procurement or GPP policies is growing, GPP in Africa is still in its infancy (Akenroye et al., 2013). According to Akenroye et al. (2013), African countries do not only lack the institutional and legal framework to implement GPP policies, but also the political commitment. The study focuses on Nigeria and states that Nigeria can learn from the experiences of other countries with regard to implementing GPP (Akenroye et al., 2013). Unfortunately, the paper does not state from which countries can be learned and it also does not mention what can be learned. This, once again, implicitly reflects the idea that the intention to learn from each other is there and can be found in the academic literature. However, there seems to be no evidence of explicit mentioning if, and how, countries have learned or can learn from each other in this case.

Another country that is still in the early stages of promoting GPP policies is China. This can be attributed to the lack of guidelines and the lower level of environmental awareness (Geng \& Doberstein, 2008). Nevertheless, Geng and Doberstein (2008) argue that an expansion of GPP is expected over time due to combined efforts of the state, industry, and scholars. Bundling strengths could be an important tool for cross-country learning opportunities because it brings both practitioners and academics together. In other words, it could illustrate the necessity to learn from each other and how crosscountry learning can benefit nations' own public procurement systems.

One of the successful innovative public procurement policies that originates from outside Europe is the SBIR (Small Business Innovation Research) program that has impacted US competitiveness by providing support for the commercialization of new technologies in technology-based SMEs (Myoken, 2010). Myoken (2010) explicitly 
states that Japan learned from this successful program in the US, but it was not explicitly described what Japan has exactly learned. Instead, the article focuses more on comparing the programs and their results with each other. It was stated that the implementation of SBIR in Japan, however, has not yet resulted in job creation, an entrepreneurial mindset, and resurrecting economic actions to the same extent as in the US. Japanese policy makers and analysts argue that the success of the SBIR program in the US is mainly a result of the support of federal agencies. According to Georghiou et al. (2014), versions of this program also exist in Australia, Belgium, the Netherlands, and the UK, but the lessons learned from one another and how these lessons have influenced their version of the SBIR program stay rather implicit. Nevertheless, comparing similar public procurement policies and initiatives as well as acknowledging that there are differences in the countries' regulatory systems could be a good starting point to start documenting cross-country learning in academic literature. By this, relevant lessons to be learned could be pointed out more explicitly without advocating that there is a one-sizefits-all approach.

To conclude, there is some mentioning in the scientific literature of cross-country learning in the sense that examples can be found of countries that have implemented similar policies and initiatives, but hard evidence for cross-country learning is lacking and the lessons learned seem to remain rather implicit. Nonetheless, this does not mean that cross-country learning is not taking place. It merely illustrates at least that cross-country learning in public procurement on sustainability and innovation is not really a research topic among academics yet. It might still be a policy theme for practitioners, but that does not explicitly transpire in academic work. Hence, we complemented the literature review by examining policy documents and by interviewing public procurement experts from a variety of countries.

\section{Policy Documents}

Our policy analysis method was used to examine policy documents and then these policy documents were used to see if these policies were formulated as a response to national policy influences and/or cross-country learning. 


\section{Public Procurement Legislation and Policy Initiatives on Sustainability and Innovation}

Although a number of countries have developed public procurement legislation and policies to promote sustainability and innovation, there seems to be a difference in pace between developing and developed countries. This can also be demonstrated by the vast majority of the retrieved literature that focuses more on developed countries. Again, this yields the impression that the process of cross-country learning in developed countries might differ from that in developing countries. More specifically, a rising number of policy initiatives and programs can be noticed for these countries. To illustrate, the EU is increasingly active in coordinating countries' sustainable and innovative public procurement policies. A lot of policy initiatives and programs that have been undertaken are voluntarily in nature. Therefore, the focus seems to be on 'soft' rather than 'hard' policy instruments to promote public procurement policies on sustainability and innovation in the EU. An example that was found of such 'soft' policy instruments are competence centers like the German KOINNO, which stands for Competence Centre for Innovative Procurement. Its aim is to increase awareness for public procurement on innovation in Germany. The general idea is that best practices with regard to public procurement (e.g. on sustainability and innovation) can be shared at such competence centers. Although these centers generally underline the importance of networking, no hard evidence of cross-country learning was found in the sense that they illustrate if, and how, there were lessons learned from such networking activities. Similarly, the use of online toolkits, in for example Sweden and the Netherlands, also seem to be popular instruments to list the requirements and to provide guidelines on how to implement sustainable practices into public procurement. To illustrate, PIANOo, the Dutch expertise center for public procurement, devotes a section of its website to sustainable public procurement. Amongst other things, the agency provides information about the environmental criteria per product group. The fact that similar policy programs and initiatives, such as competence centers and online toolkits, coexist may strengthen the idea that countries seem to be inspired by each other. However, this does not fall under the category of hard evidence, since we could not find explicit statements that demonstrate whether and what countries have learned from one another. 
Federal agencies in the United States are expected to purchase environmentally sound products and services as stipulated in the American Federal Acquisition Rules (FAR), which is more of a 'hard' policy instrument. The FAR also contains specific clauses about the renowned US SBIR program. The Netherlands did acknowledge that they were inspired by the US when launching their own version of SBIR in 2004. Nevertheless, the specific lessons learned could not be found. The SBIR can be said to have siblings in other parts of the world as well. For example, the Build in Canada Program (BCIP) is a specific program introduced by the Canadian government aimed at procuring and testing late-stage innovations prior to commercializing these innovations. In some ways, it could be argued that this program is similar to the SBIR program that also provides funding to small businesses to conduct R\&D. However, we could not find any explicit confirmation as to whether Canada has learned from the US in this regard.

On the other hand, none of the developing countries have public procurement policies for either sustainability or innovation at the moment. Nevertheless, there are signals that this situation is gradually changing and that sustainable and innovative public procurement issues are likely to be placed higher on the agenda. In particular, the public procurement laws do not currently rule out the possibility to take sustainable and innovative aspects into account during the procurement process. For instance, Bhutan is already working on a project that is called GPP Bhutan. This project was launched in 2014, but we could not find any explicit indications that they have learned from other countries in this respect even though the EU is a sponsor, which could be an opportunity for Europe to transfer its knowledge on GPP to Bhutan.

All in all, we did not find any explicit evidence of cross-country learning in policy documents, which is likely to yield the same pattern as observed from the retrieved literature. The observation and documentation of the fact that similar policy programs and initiatives exist in different parts of the world does not rule out the possibility that countries have learned from each other. From our model, it follows that inputs to develop and apply policies may either stem from national policy influences or the diffusion stage. The latter, which refers to the process of cross-country learning, was perceived to take place 'below the surface' since it is rather unclear if, and how, 
lessons learned are transferred from one country to another. The results on the analyzed policy documents, which were presented above, indicate the same implicitness of cross-country learning. A reason for this could be that cross-country learning is not considered worthwhile or appropriate to mention by policy makers, but this does not mean that cross-country learning is not happening at the policymaking level. In order to gain complementary insights, interviews were conducted with public procurement experts to find out whether they think that cross-country learning exists and to ask if they could provide hard evidence.

\section{Interviews}

After conducting interviews with ten public procurement experts from different countries including, both developing and developed countries, it appeared that the findings could be classified into three categories of countries.

\section{Familiarity with Cross-country Learning in Public Procurement}

This first section investigates to what extent countries are involved in cross-country learning in the field of public procurement and to investigate whether there are lessons learned from one country to another. The three categories of countries that we distinguished are presented in Figure 2. The first category consists of countries that think that cross-country learning exists and were able to give specific examples of if, and what, they have learned from other countries. The second category of countries thinks that crosscountry learning exists, but these countries were not able to give such examples. The third category is comprised of countries that think that cross-country learning does not take place.

The first category only consists of developing countries, which is quite remarkable. These countries indicated during the interviews that the World Bank is seen as the benchmark for establishing procurement rules and regulations. They tend to copy or slightly adapt the World Bank rules for their own regulations. For other procurement issues, such as e-procurement, they look at both developed and developing countries. One interviewee indicated that developing countries are relatively active in designing policies. Therefore, they

might be more eager to learn from other countries, which is in line 
FIGURE 2

Categorization of Cross-country Learning

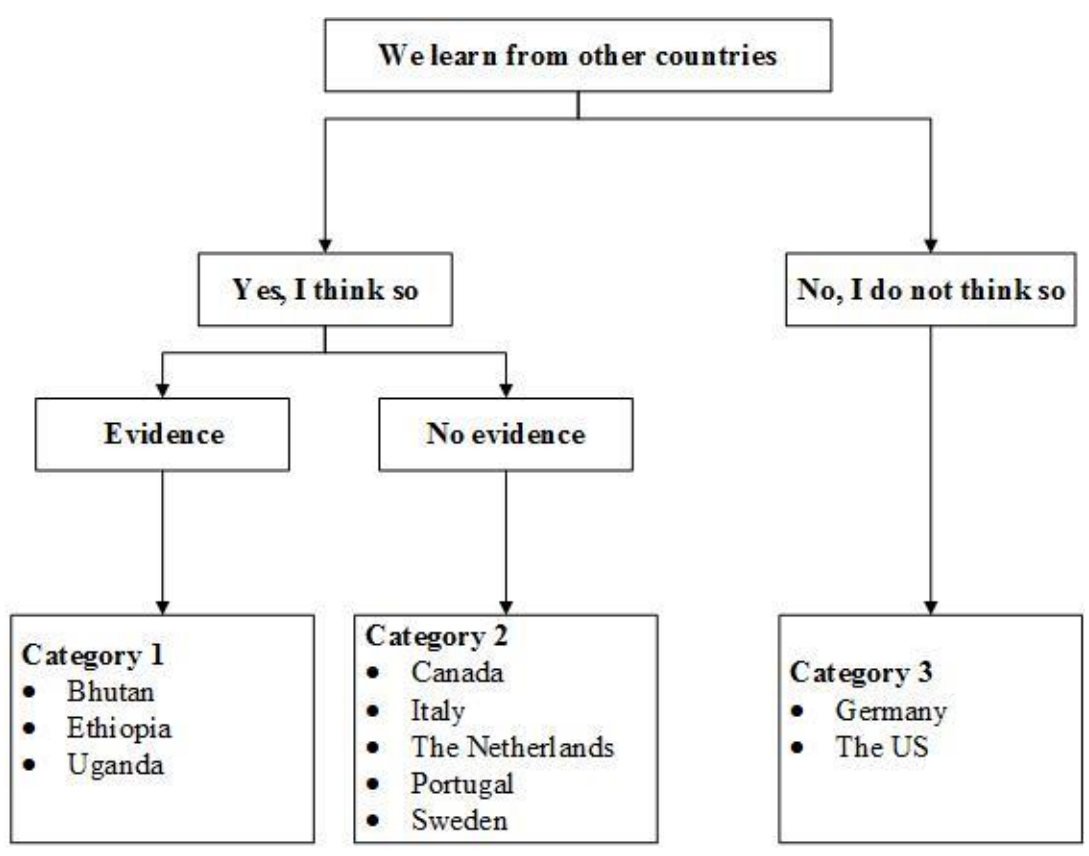

with our assumption that the cross-country learning process of developing countries differs from that of developed countries. This could be explained by the willingness of these developing countries to catch up on good public procurement practices with the rest of the world.

The second category consists of mainly European countries and Canada. This is not really surprising because the interviewee from Canada mentioned that its political system is quite similar to that of European countries. Countries within Europe have their own national procurement legislation under the umbrella of the EU Directives. The fact that their procurement rules are, therefore, quite similar may yield the impression that there is somewhat less scope or necessity to learn from each other. Hence, it might be the case that they put less effort in cross-country learning.

The third category consists of Germany and the US. The interviewees from these countries mentioned that there are many 
units of governments, which may limit cross-coordination between countries to some extent. Besides, it could also be the case that the relatively great amount of government units results in a situation in which there is already ample opportunity to learn from each other within the country's borders.

The other way around, a similar pattern could be observed for the question whether countries were familiar with countries that have learned from them. There are only a few exceptions. The first exception is Bhutan, which does not think that countries have learned from them since their public procurement system is relatively new. The other exceptions are Portugal and Italy, which do have evidence for countries that have learned from them. For instance, Portugal already made the use of e-procurement mandatory a couple of years ago, which will now gradually become mandatory in the EU.

\section{Familiarity with Cross-country Learning on Sustainability and Innovation}

All developing countries noticeably indicated that they are likely to learn from others when designing sustainable public procurement policies. These countries and also the US have mainly learned from the EU when it comes to GPP, as mentioned by the interviewees. All other developed countries, however, do not think that they learn from each other or do not have evidence to prove that. This might be due to the fact that they have their own programs or initiatives tailored to their own country's situation and requirements.

The case is a little bit different for innovation. Both developing countries, as well as developed countries, indicated that they are not likely to learn from other countries when designing public procurement policies on innovation. First of all, this could be due to the fact that countries have their own programs or initiatives, which are tailored to country-specific needs, as mentioned before. Secondly, public procurement on innovation was often not seen as their main priority. For example, the interviewee from the US stated that they tend to look at policies from a compliance perspective instead of from an innovation standpoint. As a consequence, rules are established within a legislative framework which may restrict or even hinder innovation to occur.

The other way around, it was quite surprising that all countries did not know or could not confirm whether other countries have learned 
from them when designing sustainable and/or innovative public procurement policies. The only two exceptions were Uganda and Canada. Uganda does think that other countries have learned from them because they were one of the first African countries to introduce preference and reservation schemes in which Rwanda, Tanzania, and Malawi were also interested. Canada mentioned that there were rumors that countries have looked at their Build in Canada Program (BCIP), but this has never been confirmed.

\section{Cross-country Learning Opportunities}

All countries indicated that they were open to learn more from one another. The majority stated that network activities such as congresses, conferences, and workshops are important in order to exchange experiences and knowledge. Moreover, one of the interviewees stated that sharing practices might be even more useful than sharing policies because policies are effectuated at the practice level. This demonstrates that it is important to look at cross-country learning from different angles. To illustrate, the US stated that it is important to look from policy maker to policy maker as well as from practitioner to practitioner.

In conclusion, cross-country learning seems to take place more in developing countries than in developed countries, which again leads to the assumption that the cross-country learning process of developing countries differs from that of developed. This may be explained by the fact that they are more willing to learn since they want to catch up on 'good' public procurement practices with the rest of the world, as mentioned before. Developed countries could not really explicitly indicate whether they have learned from others when designing public procurement policies and vice versa. On the 'learning' side, countries often perceived cross-country learning to take place, but they could not provide hard evidence. In other words, they could not give specific examples of what and from whom they have learned. Therefore, it may be the case that cross-country learning takes more the form of learning in an incidental manner. As a consequence, a lot of knowledge may stay rather implicit. As additional evidence on the 'teaching' side, we did not find any hard evidence of countries that have taught another in our sample. 


\section{DISCUSSION AND CONCLUSION}

The goal of this exploratory study was to investigate to what extent cross-country learning exists and to examine if there are any lessons learned in public procurement on sustainability and innovation from one country to another. A threefold methodology was used that consisted of (1) an extensive review of scientific literature complemented by (2) a thorough examination of policy documents, and (3) interviews with ten leading public procurement experts.

First of all, no hard evidence for cross-country learning was found in the limited body of literature on national public procurement policies for sustainability and innovation, which leads us to conclude that cross-country learning in public procurement on sustainability and innovation, is not really a hot topic in the literature yet. Although some examples of countries that have similar policies and initiatives in place were found in the literature, there were no explicit examples of if, and what, countries have learned from each other in this respect. Thus, this serves as a first indicator that the lessons learned seem to remain rather implicit.

Secondly, our policy document search yields similar results. Again, hard evidence on lessons learned from one country to another was lacking, which is in line with the process of diffusion that refers to cross-country learning and is seen as implicit in our model. It could be that policymakers do not consider cross-country learning as worthwhile or appropriate to mention. However, this does not mean that cross-country learning is not happening, as illustrated by the existence of similar versions of policy programs and initiatives in our policy document search.

Lastly, in contrast to the literature and policy document search, the interviews led to some striking results. To illustrate, the crosscountry process of developing countries seems to differ from that of developed countries. Developing countries indicated that they have learned from other countries and they could also provide evidence for that. On the other hand, most developed countries pointed out that they think that cross-country learning takes place, but this could not be confirmed with specific examples. The fact that these countries were not able to provide evidence could indicate that cross-country learning takes place in a more incidental manner that remains largely implicit. 
Overall, our results show that the implicitness of cross-country learning seems to be persistent, as shown by the lack of hard evidence on lessons learned in scientific literature, policy documents, and interviews. In order to develop a better understanding of crosscountry learning (in both developed and developing nations) and how it can benefit public procurement in areas such as sustainability and innovation, more research is needed.

It should be noted that this exploratory study is subject to some limitations. The first one is that this study focused on sustainability (or rather GPP) and innovation. Other policy areas such as minority assistance and SME involvement may yield other results. Second, despite the fact that our sample composition was quite international, we do not have evidence from all continents and not all continents are represented equally well as e.g. Europe in this sample. Our sample distribution is skewed further because we only examined policy documents that were available in English and conducted interviews with public procurement experts in English. Third, the public procurement experts voluntarily engaged in our interviews, which might imply that they already have some kind of interest or are more engaged in cross-country learning than others. Lastly, this study focuses on the country level and ignores local government learning or other public sectors. Despite these limitations, the analysis of crosslearning among different government levels and sectors could be a relevant contribution to further policy goals through public procurement as mentioned above.

\section{ACKNOWLEDGEMENTS}

We thank the interviewees who were kindly willing to participate in this study and provided us with valuable insights.

\section{REFERENCES}

Adler, E., \& Clark, R. (2015). An Invitation to Social Research: How It's Done (5th ed.). Stamford, US: Cengage Learning.

Akenroye, T., Oyegoke, A., \& Eyo, A. (2013). "Development of a Framework for the Implementation of Green Public Procurement in Nigeria." International Journal of Procurement Management, 6(1): 1-23. 
Amann, M., Roehrich, J., Eßig, M., \& Harland, C. (2014). “Driving Sustainable Supply Chain Management in the Public Sector: The Importance of Public Procurement in the European Union." Supply Chain Management: An International Journal, 19(3): 351-366.

Brammer, S., \& Walker, H. (2011). "Sustainable Procurement in the Public Sector: An International Comparative Study." International Journal of Operations \& Production Management, 31(4): 452476.

Edler, J., \& Georghiou, L. (2007). "Public Procurement and Innovation: Resurrecting the Demand Side." Research Policy, 36: 949-963.

European Commission (2011). Buying Green: A Handbook on Green Public Procurement. Brussels, Belgium: European Union.

European Commission (2015). Barriers to the Take-up of GPP. [Online]. Available at http://ec.europa.eu/environment/gpp/ barriers_en.htm.

European Commission. (2016). International public procurement. [Online]. Available at http://ec.europa.eu/growth/singlemarket/public-procurement/international/index_en.htm.

European Directives. (2014). “Directive 2014/24/EU." Official Journal of the European Union.

European Parliament (2010). The impact of the Lisbon Treaty in the Field of Public Procurement. Brussels, Belgium: Rösenkotter, A. \& Wuersig, $\mathrm{T}$.

Geng, Y., \& Doberstein, B. (2008). "Greening Government Procurement in Developing Countries: Building Capacity in China." Journal of Environmental Management, 88(4): 932-938.

Georghiou, L., Edler, J., Uyarra, E., \& Yeow, J. (2014). “Policy Instruments for Public Procurement of Innovation: Choice, Design and Assessment." Technological Forecasting and Social Change, 86: 1-12.

Ghauri, P., \& Grønhaug, K. (2010). Research Methods in Business Studies: A Practical Guide (4th ed.). New York, US: Prentice-Hall.

Grix, J. (2004). The Foundations of Research. Basingstoke, UK: Palgrave Macmillan. 
Harland, C., Telgen, J., \& Callender, G (2013). “International Research Study of Public Procurement." In C. Harland, G. Nassimbeni \& E. Schneller (Eds.), The Sage Handbook of Strategic Supply Management (pp. 374-401). Thousand Oaks, US: Sage.

ICLEI (2007). The Procura+ Manual - A Guide to Cost-Effective Sustainable Public Procurement. Freiburg, Germany: Clement, S.

Kable, A., Pich, J., \& Maslin-Prothero, S. (2012). "A Structured Approach to Documenting A Search Strategy for Publication: A 12 Step Guideline for Authors." Nurse Education Today, 32: 878886.

Kalvet, T., \& Lember, V. (2010). "Risk Management in Public Procurement for Innovation: The Case of Nordic-Baltic Sea Cities." Innovation, 23(3): 241-262.

Knight, L., Caldwell, N., Harland, C., \& Telgen, J. (2004). “Government Reform and Public Procurement: Academic Report of the First Workshop." Bath, UK: Centre for Research in Strategic Purchasing and Supply, University of Bath School of Management.

Lember, V., Kattel, R., \& Kalvet, T. (2014). Public Procurement, Innovation and Policy: International Perspectives. Heidelberg, Germany: Springer.

Ministerie van Infrastructuur en Milieu (2010). Handleiding duurzaam inkopen voor overheidsinkopers. The Hague, the Netherlands.

Myoken, Y. (2010). "Demand-Orientated Policy on Leading-Edge Industry and Technology: Public Procurement for Innovation." International Journal of Technology Management, 49(1): 196219.

Office of Government Commerce (2007). Finding and Procuring Innovative Solutions. Norwich, UK: Court, R.

PIANOo (2011). Procurement for Innovative Proposals. The Hague, the Netherlands: PIANOo-Dept Public Sector Purchase Management.

Procurement of Innovation Platform (2014). Guidance for Public Authorities on Public Procurement of Innovation. Freiburg, Germany. 
Rolfstam, M. (2009). "Public Procurement as an Innovation Policy Tool: The Role of Institutions." Science and Public Policy, 36(5): 349-360.

Rolfstam, M. (2013). Public Procurement and Innovation: The Role of Institutions. Cheltenham, UK: Edward Elgar Publishing.

Snider, K., \& Rendon, R. (2008). "Public Procurement Policy: Implications for Theory and Practice." Journal of Public Procurement, 8(3): 310-333.

Solomon, D. (2007). "The Role of Peer Review Scholarly Journals in the Information Age." The Journal of Electronic Publishing, 10(1).

Sustainable Procurement Task Force (2006). Procuring the Future Sustainable Procurement National Action Plan. London, UK.

UNEP (2013). Sustainable Public Procurement: A Global View. Paris, France.

United Nations (2008). Public Procurement as a Tool for Promoting More Sustainable Consumption and Production Patterns. New York, US: Kjöllerström, M.

Walker, H., \& Brammer, S. (2009). "Sustainable Procurement in the United Kingdom Public Sector." Supply Chain Management: An International Journal, 14(2): 128-137.

APPENDIX 1A

Search Process in Scopus

\begin{tabular}{|c|c|c|c|}
\hline Step & Date & Query & $\begin{array}{l}\mathrm{Re}- \\
\text { sults }\end{array}$ \\
\hline $\begin{array}{l}\text { 1: Search for } \\
\text { papers on public } \\
\text { procurement in } \\
\text { title, abstract and } \\
\text { keywords } \\
\text { published in the } \\
\text { field of Social } \\
\text { Sciences \& } \\
\text { Humanities since } \\
\text { the 1990s }\end{array}$ & $\begin{array}{l}\text { 06-19- } \\
2015\end{array}$ & $\begin{array}{l}\text { TITLE-ABS-KEY (public OR government } \\
\text { AND procurement AND policy) AND DOC- } \\
\text { TYPE (ar) AND SUBJAREA (mult OR arts } \\
\text { OR busi OR deci OR econ OR psyc OR } \\
\text { soci) AND PUBYEAR > } 1989\end{array}$ & 804 \\
\hline
\end{tabular}


APPENDIX 1A (Continued)

\begin{tabular}{|c|c|c|c|}
\hline Step & Date & Query & $\begin{array}{l}\mathrm{Re}- \\
\text { sults }\end{array}$ \\
\hline $\begin{array}{l}\text { 2: Search within } \\
\text { for papers } \\
\text { directed at } \\
\text { sustainability or } \\
\text { innovation }\end{array}$ & $\begin{array}{l}06-19- \\
2015\end{array}$ & $\begin{array}{l}\text { Sustainability } \\
\text { (TITLE-ABS-KEY (public OR Government } \\
\text { AND procurement AND policy) AND DOCTY } \\
\text { PE (ar) AND SUBJAREA (mult OR arts ORbu } \\
\text { si OR deci OR econ OR psyc OR soci) } \\
\text { ANDPUBYEAR > 1989) AND (sustainability } \\
\text { OR sustainable OR green OR } \\
\text { environmental) } \\
\text { Innovation } \\
\text { (TITLE-ABS-KEY (public OR government } \\
\text { AND procurement AND policy) AND DOCTY } \\
\text { PE(ar) AND SUBJAREA (mult OR arts ORbu } \\
\text { Si OR deci OR econ OR psyc OR soci) AND } \\
\text { PUBYEAR > 1989) AND (innovation } \\
\text { OR innovative ) }\end{array}$ & 230 \\
\hline $\begin{array}{l}\text { 3: Limit to papers } \\
\text { in journals } \\
\text { available in } \\
\text { English }\end{array}$ & $\begin{array}{l}\text { 06-19- } \\
2015\end{array}$ & $\begin{array}{l}\text { Sustainability } \\
\text { (TITLE-ABS-KEY (public OR government } \\
\text { AND procurement AND policy) AND } \\
\text { DOCTYPE (ar) AND SUBJAREA (mult OR } \\
\text { arts OR busi OR Deci OR econ OR psy OR } \\
\text { soci) ANDPUBYEAR > 1989) AND (sustaina } \\
\text { bility OR sustainable OR green OR } \\
\text { environmental) AND (LIMITTO (LANGUAGE, } \\
\text { "English")) AND (LIMIT-TO (SRCTYPE, "j")) }\end{array}$ & 220 \\
\hline $\begin{array}{l}\text { 3: Limit to papers } \\
\text { in journals } \\
\text { available in English }\end{array}$ & $\begin{array}{l}\text { 06-19- } \\
2015\end{array}$ & $\begin{array}{l}\text { Innovation } \\
\text { (TITLE-ABS-KEY (public OR government AND } \\
\text { procurement AND policy) AND DOCTYPE } \\
\text { (ar) AND SUBJAREA (mult OR } \\
\text { arts OR busi OR deci OR econ OR psyc OR } \\
\text { soci) AND PUBYEAR >1989) AND ( innovatio } \\
\text { n OR innovative ) AND (LIMITTO ( LANGUA } \\
\text { G, "English")) AND (LIMIT-TO (SRCTYPE, "j")) }\end{array}$ & 207 \\
\hline $\begin{array}{l}\text { 4. Select papers on } \\
\text { title, abstract (and } \\
\text { global overview in } \\
\text { case of doubt) } \\
\text { based on inclusion } \\
\text { criteria and } \\
\text { exclusion criteria }\end{array}$ & $\begin{array}{l}\text { 06-19- } \\
2015\end{array}$ & $\begin{array}{l}\text { Sustainability } \\
\text { An overview of these papers can be found in } \\
\text { Appendix 1B } \\
\text { Innovation } \\
\text { An overview of these papers can be found in } \\
\text { Appendix 1C }\end{array}$ & 9 \\
\hline
\end{tabular}


APPENDIX 1B

Overview of Sustainability Papers

\begin{tabular}{|c|c|c|c|}
\hline Title & Author(s) & Year & Journal \\
\hline $\begin{array}{l}\text { Development of a framework } \\
\text { for the implementation of } \\
\text { green public procurement in } \\
\text { Nigeria }\end{array}$ & $\begin{array}{l}\text { Akenroye, } \\
\text { Oyegoke \& Eyo }\end{array}$ & 2013 & $\begin{array}{l}\text { International Journal } \\
\text { of Procurement } \\
\text { Management } 6 \text { (1) }\end{array}$ \\
\hline $\begin{array}{l}\text { Driving sustainable supply } \\
\text { chain management in the } \\
\text { public sector: The importance } \\
\text { of public procurement in the } \\
\text { European Union }\end{array}$ & $\begin{array}{l}\text { Amann, } \\
\text { Roehrich, Eßig } \\
\text { \& Harland }\end{array}$ & 2014 & $\begin{array}{l}\text { Supply Chain } \\
\text { Management, } 19 \text { (3) }\end{array}$ \\
\hline $\begin{array}{l}\text { Protecting the environment } \\
\text { through public procurement: } \\
\text { The case of South Africa* }\end{array}$ & Bolton & 2008 & $\begin{array}{l}\text { Natural Resources } \\
\text { Forum, } 32 \text { (1) }\end{array}$ \\
\hline $\begin{array}{l}\text { Sustainable procurement in } \\
\text { the public sector: An } \\
\text { international comparative } \\
\text { study }\end{array}$ & $\begin{array}{l}\text { Brammer \& } \\
\text { Walker }\end{array}$ & 2011 & $\begin{array}{l}\text { International Journal } \\
\text { of Operations and } \\
\text { Production } \\
\text { Management, } 31 \text { (4) }\end{array}$ \\
\hline $\begin{array}{l}\text { Green public procurement in } \\
\text { practice - The case of Norway }\end{array}$ & $\begin{array}{l}\text { Fet, Michelsen } \\
\text { \& de Boer }\end{array}$ & 2011 & $\begin{array}{l}\text { Society and } \\
\text { Economy, } 33 \text { (1) }\end{array}$ \\
\hline $\begin{array}{l}\text { Greening government } \\
\text { procurement in developing } \\
\text { countries: Building capacity in } \\
\text { China* }\end{array}$ & $\begin{array}{l}\text { Geng \& } \\
\text { Doberstein }\end{array}$ & 2008 & $\begin{array}{l}\text { Journal of } \\
\text { Environmental } \\
\text { Management, } 88 \text { (4) }\end{array}$ \\
\hline $\begin{array}{l}\text { Environmental criteria in the } \\
\text { public purchases above the } \\
\text { EU threshold values by three } \\
\text { Nordic countries: } 2003 \text { and } \\
2005\end{array}$ & $\begin{array}{l}\text { Nissinen, } \\
\text { Parikka-Alhola } \\
\text { \& Rita }\end{array}$ & 2009 & $\begin{array}{l}\text { Ecological } \\
\text { Economics, } 68 \text { (6) }\end{array}$ \\
\hline $\begin{array}{l}\text { Public policies on CSR in } \\
\text { Europe: Themes, Instruments } \\
\text { and Regional Differences }\end{array}$ & $\begin{array}{l}\text { Steurer, } \\
\text { Martinuzzi \& } \\
\text { Margula }\end{array}$ & 2012 & $\begin{array}{l}\text { Corporate Social } \\
\text { Responsibility \& } \\
\text { Environmental } \\
\text { Management, } 19 \\
\end{array}$ \\
\hline $\begin{array}{l}\text { Sustainable procurement in } \\
\text { the United Kingdom public } \\
\text { sector* }\end{array}$ & $\begin{array}{l}\text { Walker \& } \\
\text { Brammer }\end{array}$ & 2009 & $\begin{array}{l}\text { Supply Chain } \\
\text { Management, } 14 \text { (2) }\end{array}$ \\
\hline
\end{tabular}

Note: *Found via back referencing. 
APPENDIX 1C

Overview of Innovation Papers

\begin{tabular}{|l|l|l|l|}
\hline \multicolumn{1}{|c|}{ Title } & \multicolumn{1}{|c|}{ Author(s) } & Year & \multicolumn{1}{|c|}{ Journal } \\
\hline $\begin{array}{l}\text { The public sector as first user } \\
\text { of innovations }\end{array}$ & $\begin{array}{l}\text { Dalpé, DeBresson } \\
\text { \& Xiaoping }\end{array}$ & 1992 & $\begin{array}{l}\text { Research Policy, } \\
21 \text { (3) }\end{array}$ \\
\hline $\begin{array}{l}\text { Public procurement and } \\
\text { innovation - Resurrecting the } \\
\text { demand side }\end{array}$ & $\begin{array}{l}\text { Edler \& } \\
\text { Georghiou }\end{array}$ & 2007 & $\begin{array}{l}\text { Research Policy, } \\
36\end{array}$ \\
\hline $\begin{array}{l}\text { Public procurement for } \\
\text { innovation as mission-oriented } \\
\text { innovation policy }\end{array}$ & $\begin{array}{l}\text { Edquist } \\
\text { \& Zabala- } \\
\text { Iturriagagoitia }\end{array}$ & 2012 & $\begin{array}{l}\text { Research Policy, } \\
41 \text { (10) }\end{array}$ \\
\hline $\begin{array}{l}\text { Policy instruments for public } \\
\text { procurement of innovation: } \\
\text { Choice, design and } \\
\text { assessment }\end{array}$ & $\begin{array}{l}\text { Georghiou, Edler, } \\
\text { Uyarra \& Yeow }\end{array}$ & 2014 & $\begin{array}{l}\text { Technological } \\
\text { Forecasting and } \\
\text { Social Change, } \\
86\end{array}$ \\
\hline $\begin{array}{l}\text { Demand-oriented policy on } \\
\text { leading-edge industry and } \\
\text { technology: Public } \\
\text { procurement for innovation }\end{array}$ & Myoken & 2010 & $\begin{array}{l}\text { International } \\
\text { Journal of Tech- } \\
\text { nology Manage- } \\
\text { ment, 49 (1-3) }\end{array}$ \\
\hline $\begin{array}{l}\text { Public procurement as an } \\
\text { innovation policy tool: The role } \\
\text { of institutions }\end{array}$ & Rolfstam & 2009 & $\begin{array}{l}\text { Science and } \\
\text { Public Policy, 36 } \\
(5)\end{array}$ \\
\hline $\begin{array}{l}\text { Public procurement of } \\
\text { innovation policy: Competition } \\
\text { regulation, market structure } \\
\text { and dominant design }\end{array}$ & Wan & 2014 & $\begin{array}{l}\text { Journal of Public } \\
\text { Procurement, 14 } \\
\text { (4) }\end{array}$ \\
\hline
\end{tabular}

APPENDIX 2A

Overview of Government Websites and Procurement Associations

\begin{tabular}{|l|l|l|}
\hline Country & Government Website & Procurement Association \\
\hline Bhutan & http://www.pppd.gov.bt & \\
\hline Canada & https://buyandsell.gc.ca & http://www.scmanational.ca \\
\hline Ethiopia & http://www.ppa.gov.et & \\
\hline Germany & http://www.bmwi.de/EN/root.html & http://www.bme.de/en/start \\
\hline Italy & http://www.consip.it/en & http://www.adaci.it \\
\hline $\begin{array}{l}\text { Nether- } \\
\text { lands }\end{array}$ & $\begin{array}{l}\text { http://www.rijksoverheid.nl/onderw } \\
\text { erpen/inkopen-door-het-rijk }\end{array}$ & http://www.nevi.nl \\
\hline Portugal & $\begin{array}{l}\text { https://www.espap.pt/Paginas/ho } \\
\text { me.aspx* }\end{array}$ & http://www.apcadec.org.pt \\
\hline Sweden & http://www.konkurrensverket.se/en & http://www.silf.se/in-english \\
\hline
\end{tabular}




\section{APPENDIX 2A (Continued)}

\begin{tabular}{|l|l|l|}
\hline Country & Government Website & Procurement Association \\
\hline Uganda & http://www.ppda.go.ug & http://www.ippu.or.ug \\
\hline $\begin{array}{l}\text { United } \\
\text { States }\end{array}$ & http://www.gsa.gov & http://www.nigp.org/eweb \\
\hline
\end{tabular}

Note: *Not accessible due to language difficulties.

\section{APPENDIX 2B \\ Overview of Public Procurement Legislation and Policy Initiatives on Sustainability}

\begin{tabular}{|l|l|l|}
\hline \multicolumn{1}{|c|}{ Country } & Public Procurement Legislation & \multicolumn{1}{|c|}{ Policy Initiatives } \\
\hline Bhutan & $\begin{array}{l}\text { Procurement Rules and } \\
\text { Regulations, 2009 (revised in } \\
\text { 2015): } \\
\text { http://pppd.gov.bt:8888/EGP/ } \\
\text { PRR_and_Amendments/Procur } \\
\text { ement\%20Rules\%20and\%20R } \\
\text { egulations.pdf }\end{array}$ & $\begin{array}{l}\text { GPP Bhutan, and funded by } \\
\text { the EU, founded in 2014: }\end{array}$ \\
\hline Canada & $\begin{array}{l}\text { Key Policies and Directives } \\
\text { (last modified in 2015): } \\
\text { https://buyandsell.gc.ca/policy } \\
\text {-and-guidelines/Policy-and- } \\
\text { Legal-Framework/Key-Policies- } \\
\text { and-Directives }\end{array}$ & $\begin{array}{l}\text { Policy on Green Procurement, } \\
\text { effective as of 2006: } \\
\text { http://tpsgc-pwgsc.gc.ca/ } \\
\text { ecologisation-greening/ } \\
\text { achats-procurement/ } \\
\text { politique-policy-eng.html }\end{array}$ \\
\hline Ethiopia & $\begin{array}{l}\text { Federal Public Procurement } \\
\text { Directive, 2010: } \\
\text { http://ppa.gov.et/index.php?o } \\
\text { ption=com_joomdoc\&view=doc } \\
\text { man\&gid=80\&task=cat_view\&l } \\
\text { temid=159 }\end{array}$ & \\
\hline Italy & $\begin{array}{l}\text { Competition Act - GWB } \\
\text { (amended version expected to } \\
\text { enter into force in 2016): } \\
\text { http://gesetze-im-internet. } \\
\text { de/englisch_gwb/index.html }\end{array}$ & $\begin{array}{l}\text { Green Public Procurement by } \\
\text { the UBA administered by the } \\
\text { Federal Environment Agency: } \\
\text { http://umweltbundesamt.de/e } \\
\text { n/topics/economics- } \\
\text { consumption/green-public- } \\
\text { procurement }\end{array}$ \\
\hline Germany & \\
\hline & & \\
\hline
\end{tabular}


APPENDIX 2B (Continued)

\begin{tabular}{|c|c|c|}
\hline Country & Public Procurement Legislation & Policy Initiatives \\
\hline Netherlands & $\begin{array}{l}\text { Aanbestedingswet, } 2012 \\
\text { (amended version is expected } \\
\text { to enter into force in 2016): } \\
\text { http://wetten.overheid.nl/BWB } \\
\text { R0032203/2016-07-01 }\end{array}$ & $\begin{array}{l}\text { Sustainable Procurement by } \\
\text { PIANOo administered by the } \\
\text { Ministry of Economic Affairs: } \\
\text { https://pianoo.nl/themas/ma } \\
\text { atschappelijk-verantwoord- } \\
\text { inkopen-duurzaam-inkopen/ }\end{array}$ \\
\hline \multicolumn{3}{|l|}{ Portugal } \\
\hline Sweden & $\begin{array}{l}\text { Swedish Public Procurement } \\
\text { Act, } 2007 \text { (amended version is } \\
\text { expected to enter into force in } \\
\text { 2016): } \\
\text { http://konkurrensverket.se/glo } \\
\text { balassets/english/publications } \\
\text {-and-decisions/swedish-public- } \\
\text { procurement-act.pdf }\end{array}$ & $\begin{array}{l}\text { Sustainable Procurement } \\
\text { Criteria administered by the } \\
\text { Swedish Competition } \\
\text { Authority: } \\
\text { http://konkurrensverket.se/en } \\
\text { /publicprocurement/sustainab } \\
\text { le-public-procurement/use- } \\
\text { sustainable- } \\
\text { criteria/sustainable- } \\
\text { procurement-criteria/ }\end{array}$ \\
\hline Uganda & $\begin{array}{l}\text { The Public Procurement and } \\
\text { Disposal of Public Assets (rules } \\
\text { and methods for procurement } \\
\text { of supplies, works and non- } \\
\text { consultancy services) } \\
\text { Regulations, 2014: } \\
\text { https://ppda.go.ug/regulations } \\
\text {-2/ }\end{array}$ & \\
\hline $\begin{array}{l}\text { United } \\
\text { States }\end{array}$ & $\begin{array}{l}\text { Federal Acquisition Regulation, } \\
\text { effective as of 2015: } \\
\text { https://acquisition.gov/sites/d } \\
\text { efault/files/current/far/pdf/FA } \\
\text { R.pdf }\end{array}$ & $\begin{array}{l}\text { Buy Green Products, Services, } \\
\text { and Vehicles administered by } \\
\text { the GSA: } \\
\text { http://gsa.gov/portal/category } \\
/ 27116\end{array}$ \\
\hline
\end{tabular}

\section{APPENDIX 2C \\ Overview of Public Procurement Legislation and Policy Initiatives on Innovation}

\begin{tabular}{|c|l|c|}
\hline Country & \multicolumn{1}{|c|}{ Public Procurement Legislation } & Policy Initiatives \\
\hline Bhutan & Procurement Rules and Regulations, & \\
& 2009 (revised in 2015): \\
& http://pppd.gov.bt:8888/EGP/PRR_a & \\
& nd_Amendments/Procurement\%20Ru & \\
& les\%20and\%20Regulations.pdf & \\
\hline
\end{tabular}




\section{APPENDIX 2C (Continued)}

\begin{tabular}{|c|c|c|}
\hline Country & Public Procurement Legislation & Policy Initiatives \\
\hline Canada & $\begin{array}{l}\text { Key Policies and Directives (last } \\
\text { modified in 2015): } \\
\text { https://buyandsell.gc.ca/policy-and- } \\
\text { guidelines/Policy-and-Legal- } \\
\text { Framework/Key-Policies-and- } \\
\text { Directives }\end{array}$ & $\begin{array}{l}\text { Build in Canada } \\
\text { Innovation Program, } \\
\text { founded in 2010: } \\
\text { https://buyandsell.gc.ca/i } \\
\text { nitiatives-and- } \\
\text { programs/build-in- } \\
\text { canada-innovation- } \\
\text { program-bcip }\end{array}$ \\
\hline Ethiopia & $\begin{array}{l}\text { Federal Public Procurement } \\
\text { Directive, 2010: } \\
\text { http://ppa.gov.et/index.php?option } \\
=\text { com_joomdoc\&view=docman\&gid } \\
=80 \& \text { task=cat_view\&ltemid=159 }\end{array}$ & \\
\hline Germany & $\begin{array}{l}\text { Competition Act - GWB (amended } \\
\text { version is expected to enter into } \\
\text { force in 2016) } \\
\text { http://gesetze-im-internet.de/ } \\
\text { englisch_gwb/index.html }\end{array}$ & $\begin{array}{l}\text { KOINNO, administered by } \\
\text { the Federal Ministry for } \\
\text { Economic Affairs and } \\
\text { Energy, founded in } 2013 \\
\text { http://en.koinno- } \\
\text { bmwi.de/ }\end{array}$ \\
\hline \multicolumn{3}{|l|}{ Italy } \\
\hline Netherlands & $\begin{array}{l}\text { Aanbestedingswet, } 2012 \text { (amended } \\
\text { version is expected to enter into } \\
\text { force in 2016) } \\
\text { http://wetten.overheid.nl/BWBR00 } \\
32203 / 2016-07-01\end{array}$ & $\begin{array}{l}\text { Inkoop Innovatie Urgent } \\
\text { administered by the } \\
\text { Ministry of Economic } \\
\text { Affairs, started in } 2012 \\
\text { http://inkoopinnovatieurg } \\
\text { ent.nl/ } \\
\text { SBIR Program, } \\
\text { established in } 2004 \\
\text { http://rvo.nl/subsidies- } \\
\text { regelingen/overheden-en- } \\
\text { sbir }\end{array}$ \\
\hline \multicolumn{3}{|l|}{ Portugal } \\
\hline Sweden & $\begin{array}{l}\text { Swedish Public Procurement Act, } \\
2007 \text { (amended version is expected } \\
\text { to enter into force in 2016) } \\
\text { http://konkurrensverket.se/globala } \\
\text { ssets/english/publications-and- } \\
\text { decisions/swedish-public- } \\
\text { procurement-act.pdf }\end{array}$ & $\begin{array}{l}\text { VINNOVA administered by } \\
\text { a Swedish government } \\
\text { agency, founded in } 2001 \\
\text { http://vinnova.se/en/Our } \\
\text {-acitivities/Innovative } \\
\text { ness-of-specific-target- } \\
\text { groups/ }\end{array}$ \\
\hline
\end{tabular}


APPENDIX 2C (Continued)

\begin{tabular}{|l|l|l|}
\hline \multicolumn{1}{|c|}{ Country } & \multicolumn{1}{|c|}{ Public Procurement Legislation } & \multicolumn{1}{c|}{ Policy Initiatives } \\
\hline Uganda & $\begin{array}{l}\text { The Public Procurement and } \\
\text { Disposal of Public Assets (rules and } \\
\text { methods for procurement of } \\
\text { supplies, works and non- } \\
\text { consultancy services) Regulations, } \\
2014 \\
\text { https://ppda.go.ug/regulations-2/ }\end{array}$ & \\
\hline $\begin{array}{l}\text { United } \\
\text { States }\end{array}$ & $\begin{array}{l}\text { Federal Acquisition Regulation, } \\
\text { effective as of 2015 } \\
\text { https://acquisition.gov/sites/defaul } \\
\text { t/files/current/far/pdf/FAR.pdf }\end{array}$ & $\begin{array}{l}\text { Small Business } \\
\text { Innovation Research } \\
\text { Program (SBIR), } \\
\text { established in 1997 } \\
\text { https:// sbir.gov/ }\end{array}$ \\
\hline
\end{tabular}

\section{APPENDIX 3A Interview Transcript}

Dear interviewee,

Before we are going to ask you some questions, we would like to introduce ourselves. Our names are Kimberly Nijboer and Shirin Senden. We are two International Business Administration students from the University of Twente and we are currently writing our bachelor thesis on cross-country learning with regard to sustainability and innovation in public procurement. This is in regards to preparing for the sixth edition of IRSPP (International Research Study on Public Procurement).

The ways in which these sustainable and innovative policy goals have been implemented in public procurement vary per country. Furthermore, not all countries implemented their variants at the same time. This means that there is ample opportunity for cross-country learning. Therefore, we would like to ask you some questions to investigate to what extent your country is involved in cross-country learning. Before we start, are you okay with recording this conversation? Your answers will be kept confidentially and anonymously.

First of all, are you familiar with any influences or lessons learned from other countries that have helped your country in establishing policies on public procurement? In other words, do you think cross- 
country learning exists in your country? If so, please give an example. If not, why do you think so?

Secondly, do you know other countries that copied policies on public procurement that have been made in your country? If so, could you give us an example? If not, could you tell us why?

More specifically, we are looking at cross-country learning on innovative and sustainable public procurement. Are you familiar with influences or lessons learned from other countries that have helped your country in establishing innovative and sustainable policies on public procurement? If so, could you provide us with an example? If not, could you explain why?

Next, to this, do you know other countries that copied innovative and sustainable policies on public procurement that have been made in your country? If so, please give an example. If not, why do you think so?

Do you think that countries can or should learn more from each other? If so, in what ways could countries learn more from each other and why do you think this is important? If not, why do you think so?

Lastly, do you think that cross-learning opportunities exist at other levels than the country level? For example, at the local government level? Why do you think so?

Thank you very much for your willingness to cooperate. Once again, your answers will be treated confidentially and anonymously. 